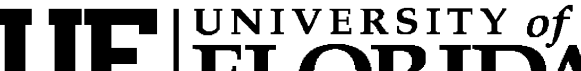 FLORIDA \\ IFAS Extension
}

EENY332

\section{Glow-Worms, Railroad-Worms (Insecta: Coleoptera: Phengodidae) 1}

Marc Branham ${ }^{2}$

\section{Introduction}

The family Phengodidae are uncommonly encountered beetles that have bioluminescent females that appear to be larvaiform (or larger versions of the immature stage.) These adult females are able to produce light from paired photic organs located on each body segment (one glowing spot on each side) and sometimes also from luminous bands that extend across the dorsal surface of the body between each body segment. Females appear to be more commonly encountered than larvae. Because these glowing spots along the females body resemble the windows of train cars internally illuminated in the night, they are often referred to as "railroad-worms."

Males of these species are not larviform, but instead resemble other beetles, though their first pair of wings (elytra) are less then half as long as their hind wings and the males of most species have very elaborate, feather-like antennae. These fancy antennae are used to detect and follow pheromones produced by the female.

\section{Distribution}

This beetle family (as defined by Lawrence et al. 1999) is restricted to the New World (from the northern U.S. to Chile) with its highest diversity in the neotropics. It is represented by approximately 25 genera. Some 181 described species are currently known to science, with perhaps 100 more already in collections that remain to be named.

The phengodid genera found in the U.S. include: Cenophengus LeConte 1881, Distremocephalus Wittmer 1975, Paraptorthodius Schaeffer 1904, Phengodes Illiger 1807, Stenophrixothrix Wittmer 1963, and Zarhipis LeConte 1881. The number of species in this family that are currently known to occur in the U.S. is 23 , with most occurring in the southwestern U.S.

Phengodid species that are known from Florida are restricted to the genus Phengodes: P. fuscipes floridensis Blatchley (which is endemic to FL, generally restricted to the south-central region of the state), P. f. intermedia Wittmer, P. laticollis meridiana Wittmer, $P$. nigromaculata Wittmer, and $P$.

1. This document is EENY-332, one of a series of Featured Creatures from the Entomology and Nematology Department, Florida Cooperative Extension Service, Institute of Food and Agricultural Sciences, University of Florida. Published: December 2004. Revised: February 2005. This document is also available on Featured Creatures Website at http://creatures.ifas.ufl.edu. Please visit the EDIS Website at http://edis.ifas.ufl.edu. Additional information on these organisms, including many color photographs, is available at the Entomology and Nematology Department website at http://entnemdept.ifas.ufl.edu/.

2. Marc Branham, assistant professor, Department of Entomology and Nematology, Institute of Food and Agricultural Sciences, University of Florida Gainesville.

The Institute of Food and Agricultural Sciences (IFAS) is an Equal Opportunity Institution authorized to provide research, educational information and other services only to individuals and institutions that function with non-discrimination with respect to race, creed, color, religion, age, disability, sex, sexual orientation, marital status, national origin, political opinions or affiliations. U.S. Department of Agriculture, Cooperative Extension Service, University of Florida, IFAS, Florida A. \& M. University Cooperative Extension Program, and Boards of County Commissioners Cooperating. Larry Arrington, Dean 
plumosa Olivier (though this last species appears to be a questionable Florida record.)

\section{Description}

Eggs: The eggs are oval and white. While eggs are known to be luminescent, they can take up to one month after being laid before they become luminous. The eggs of $Z$. integripennis are approximately 2.75 $\mathrm{mm}$ in diameter though the eggs of most species are smaller. As far as is known, eggs are laid on the ground in groups and are encircled by the female for a period of time (perhaps till they hatch). Barber (1906) reported 53 eggs being laid by a single Phengodes female.

Larvae: The last larval instar range in size from 15 to $65 \mathrm{~mm}$ in length. They are vermiform (cylindrical with short legs) and have a prognathous (pointing forward) head. Antennae are three segmented with one pair of stemmata (single lens, simple eyes) on each side of the head. Larval mandibles possess an internal channel, running from the base of the mandible to its tip. Body is smooth, moderately sclerotized and shiny. Coloration is variable.

Photic organs in Zarhipis, are present as bands (at the base of the meso and metathroax and on all but the last abdominal tergites,) or spots (on upper lateral surfaces of abdominal segments one through nine); the photic emissions generally are greenish-yellow (Tiemann 1967).

The photic organs in Phrixothrix are composed of two medial organs on the head (producing red photic emissions) and 11 pairs of photic organs (producing yellowish-green emissions) located from second thoracic segment through the ninth abdominal segment (Costa et al. 1999). The larvae are predacious and feed on millipedes.

Pupa: Pupation in Zarhipis integripennis takes 12 to 13 days for females and 20 to 35 days for males (Tiemann 1967).

Males: Adult males of various species range from approximately 6 to $35 \mathrm{~mm}$ in length. Males are often brownish to brown and black. Antennae are large, 12-segmented and bipectinate (with rami pointing forward). Mandibles are large, slender and very curved. Elytra (the forewings) are greatly shortened, narrowed toward the distal tip and somewhat leathery. Eyes are large and bulge outward from the sides of head.

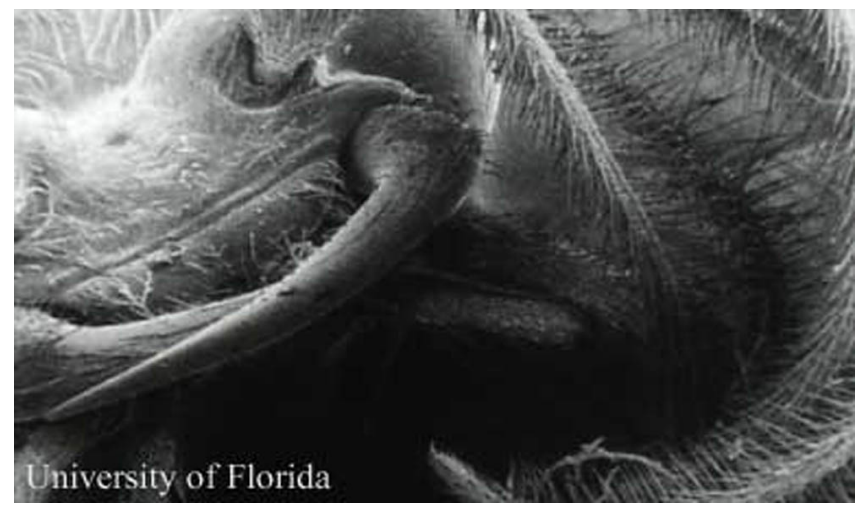

Figure 1. A scanning electron microscope image of an adult male Phengodes sp. "glow- worm," showing mandibles and antenna. Credits: Photograph by: T.C. Carlysle, University of Florida

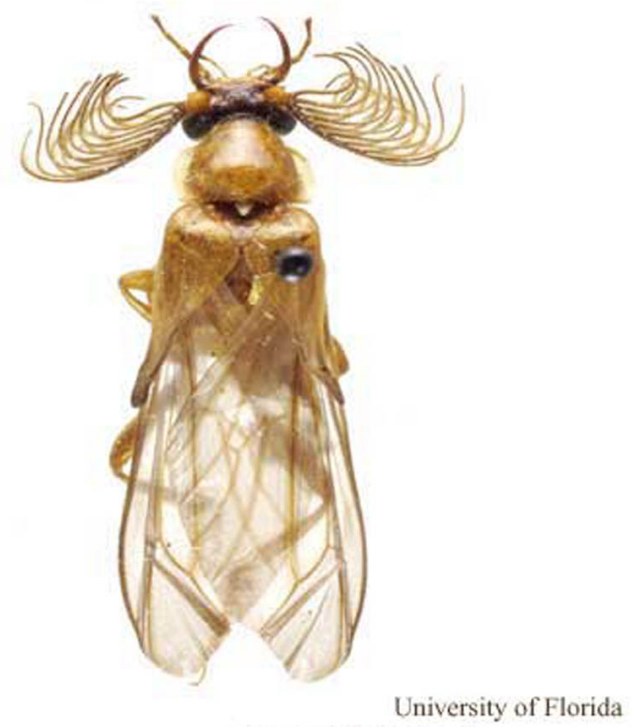

Figure 2. An adult male Phengodes plumosa "glow-worm"; dorsal view. Credits: Photograph by: Marc Branham, University of Florida

Females: Females are brownish tan to light tan with black surrounding areas of red on their dorsal surface in some taxa. Others appear a creamy-tan. Females are larviform: with a larval-like antenna bearing three segments, larval-like legs (with a single claw per leg) and a single stemmata rather than bearing a compound eye. Through rearing studies in the lab with Phrixothrix hirtus, Costa et al. (1999) were able to distinguish larviform adult females from 


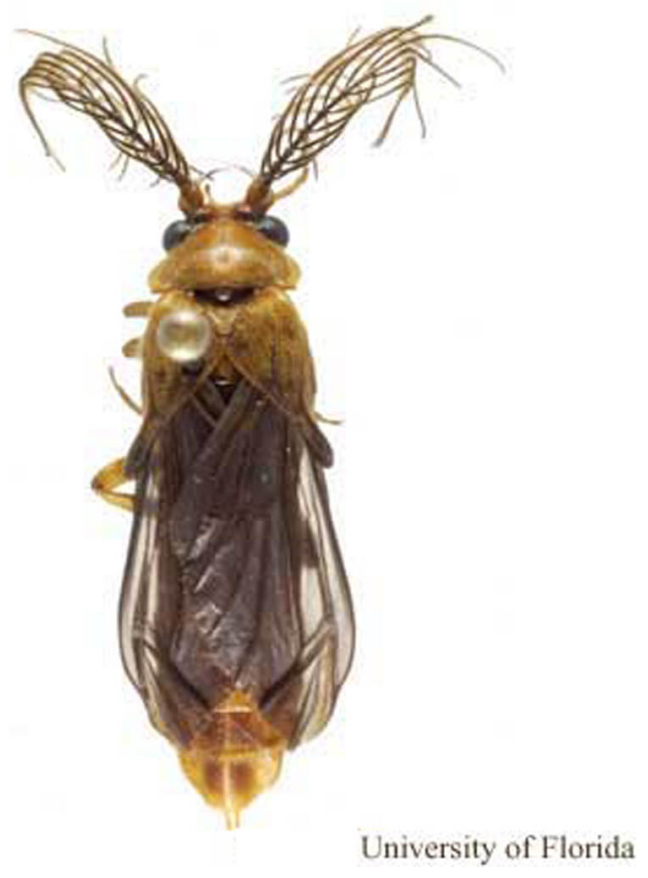

Figure 3. An adult male Phengodes laticollis "glow-worm"; dorsal view. Credits: Photograph by: Marc Branham, University of Florida

larvae "by the presence of an ooporus (the opening for the discharge of eggs) in sternite IX, which is absent in larvae; and by the annular (ring-shaped) spiracles, which are biforous (having two openings) in larvae."

The larviform females appear to be identical to the larvae in this species otherwise. Rearing studies to determine such differences in other genera have yet to be done and needs much attention. The pattern of photic organ arrangement in Zarhipis females are as found in Zarhipis larvae, plus one to three luminous spots on ventrite of abdominal segments two through nine. The arrangement in female Phrixothrix is as found in their larvae (reviewed in Branham and Wenzel 2001).

\section{Biology and Behavior}

Larvae can be found glowing both in wet soil and while on the bark or leaves of trees (though these arboreal larvae are mainly found in tropical regions where moisture levels above the ground is high.)

Even though species in this family are not well studied, the males and females appear to be the most active at night. When males are collected, they are

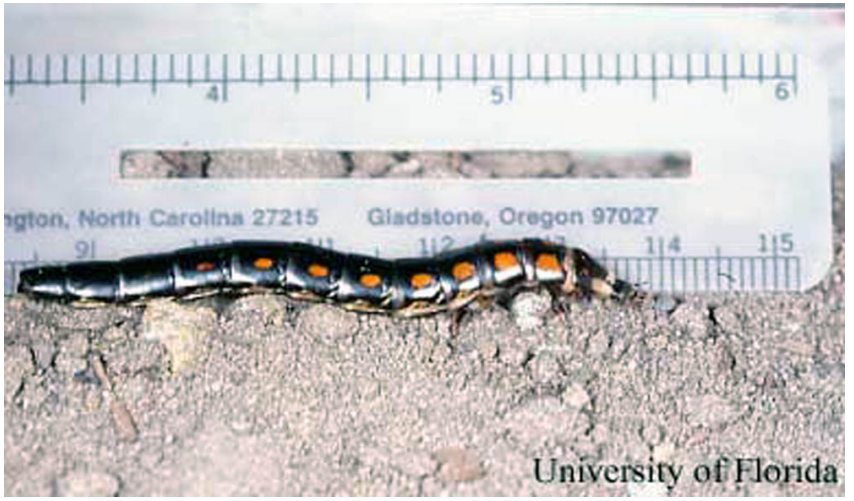

Figure 4. A female Phengodes sp. "glow-worm." Credits: Photograph by: Lyle Buss, University of Florida

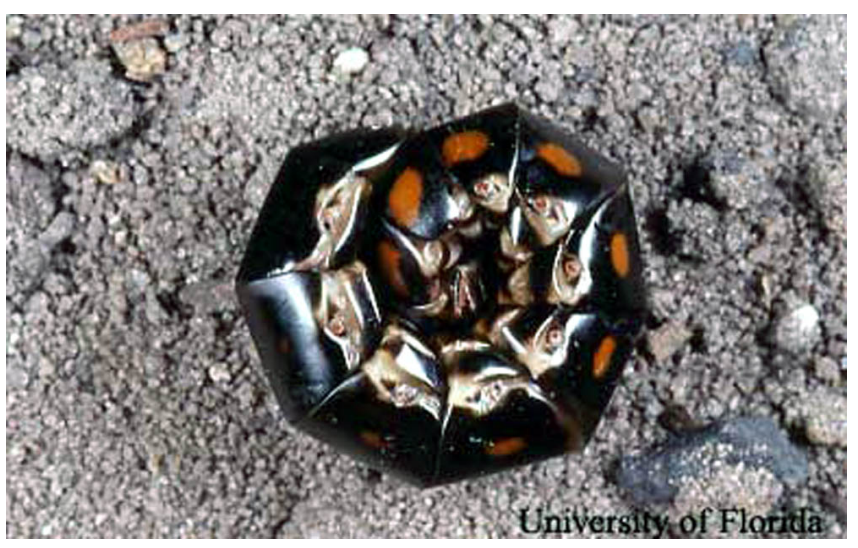

Figure 5. A female Phengodes sp. "glow-worm" curled after being disturbed. Credits: Photograph by: Lyle Buss, University of Florida

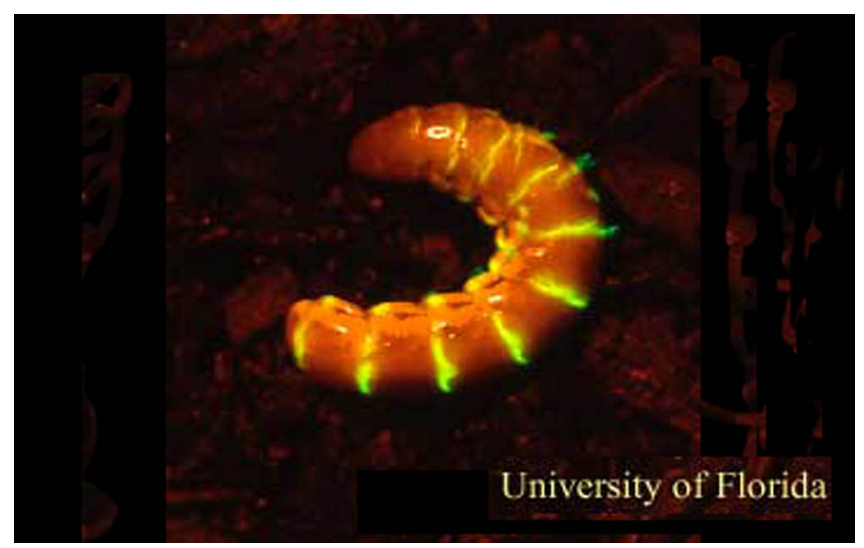

Figure 6. A female Phengodes sp. "glow-worm" glowing. Credits: Photograph by: James E. Lloyd, University of Florida

generally collected at lights and light traps in the evening. Even though females appear to hide in their burrows during the day, females can often be detected on the surface of the ground by their glowing, immediately following a summer rain. Even though the females are bioluminescent, the females light emission does not appear to be the cue that the 


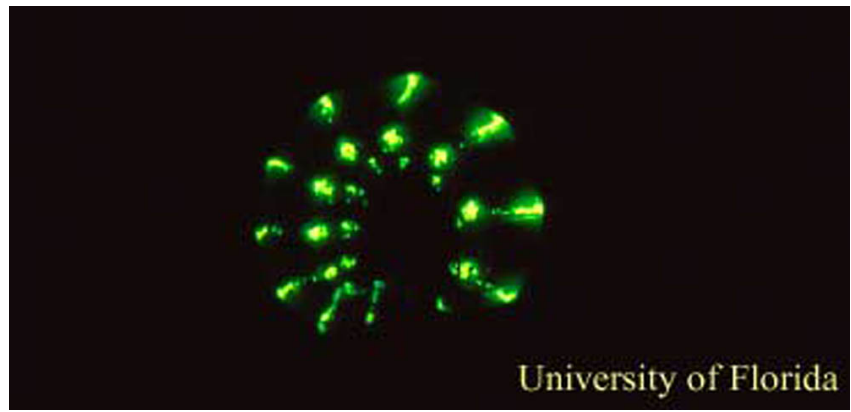

Figure 7. A female Phengodes sp. "glow-worm" curled and glowing Credits: Photograph by: James E. Lloyd, University of Florida

males use to locate their mates. Females are located by males following the females pheromone. Current evidence suggests that females are advertising their unpalatability by using their glowing as a warning signal to nocturnal predators (Viviani and Bechara 1997). Females also often glow continuously while they curl themselves around their eggs.

Phengodid males in the tribe Mastinocerini (Brasilocerus, Euryopa, Mastinocerus, Mastinomorphus, Phrixothrix, Stenophrixothrix and Taxinomastinocerus) glow from larval photic organs and are luminous throughout their adult life. Like the female photic emissions, these emissions appear to serve a defensive rather than a courtship function (Viviani and Bechara 1997). A male Cenophengus ciceroi was observed glowing from "two faint green spots, each lateral to the midline in the last abdominal segments. These spots glowed continuously and uncontrollably" (Wittmer 1981).

\section{Males from the South American genus} Pseudophengodes, have a large photic organ similar in size and shape to those found in some fireflies. These photic organs are not of larval origin and appear to be used in pair formation in these few species.

Through a modern phylogenetic analysis of the cantharoid taxa (those including Phengodidae and their closest relatives) Branham and Wenzel (2001) not only hypothesize that phengodids and fireflies are not each others closest relatives, but that bioluminescence arose twice and was lost once in this lineage of beetles. Phengodids and fireflies (family Lampyridae) have traditionally been thought to be each others closest relative, mainly due to the fact both families are bioluminescent.

\section{Rearing Larvae}

Rearing phengodid larvae is a difficult task that requires patience, skill and luck. Success is more likely if late instar larvae are field collected and reared in the lab to the adult stage. Tiemann (1967) had success rearing $Z$. integripennis (an arid species) by keeping early instars in 10x10x6 cm covered plastic refrigerator containers with about $3 \mathrm{~cm}$ of moist, fine sand in the bottom. Holes were made in the cover to allow gas exchange, but some larvae apparently escaped through these holes.

For larger larvae, Tiemann found the best method for rearing this species involved "a 40x35 cm plastic wastebucket fitted with a screened drain $(1 \mathrm{~cm}$ dia.) at the bottom. This bucket was then filled to about $8 \mathrm{~cm}$ from the top with sand and moistened. The larvae that were added in April were not watered again until fall (October 11). Five days after this second watering the larvae were removed (they were found at depths ranging from 22 to $32 \mathrm{~cm}$ ) and added to smaller containers with moist sand and several millipedes for food. Soon after being added to the smaller containers with the millipedes, the larvae began to feed." Tiemann pointed out that millipedes could also be kept for a period of time in this manner, as they burrow into the sand as it dries out. No additional notes or suggestions on rearing $Z$. integripennis were mentioned in Tiemann (1967).

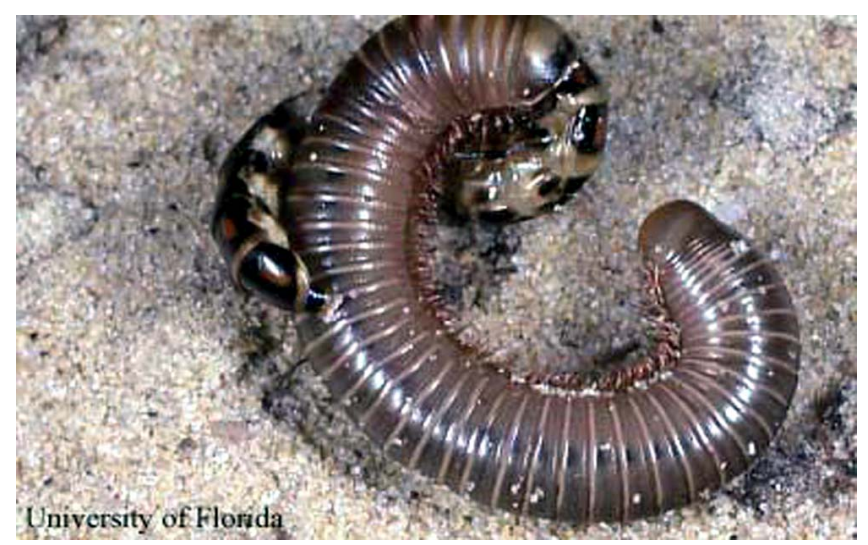

Figure 8. Phengodes sp. railroad-worm feeding on a millipede, Gainesville, FL. Credits: Photograph by: Lyle Buss, University of Florida 


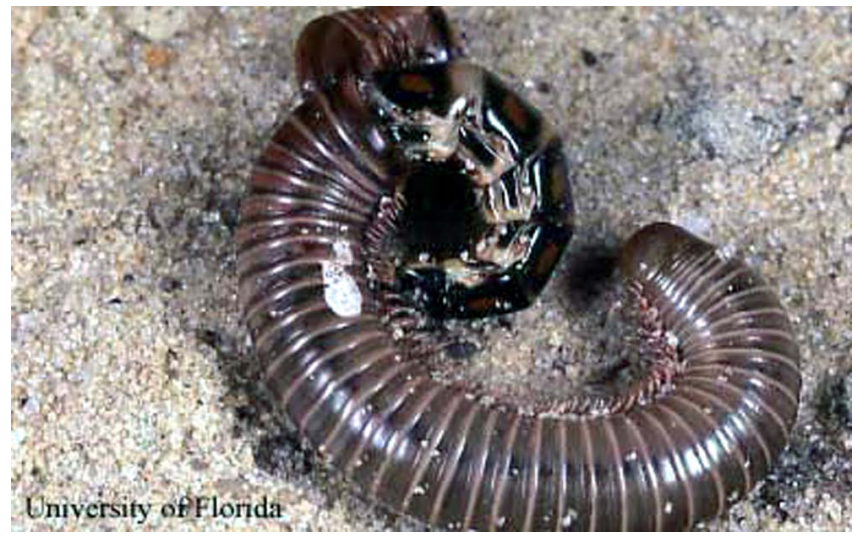

Figure 9. Phengodes sp. railroad-worm feeding on a millipede, Gainesville, FL. Credits: Photograph by: Lyle Buss, University of Florida

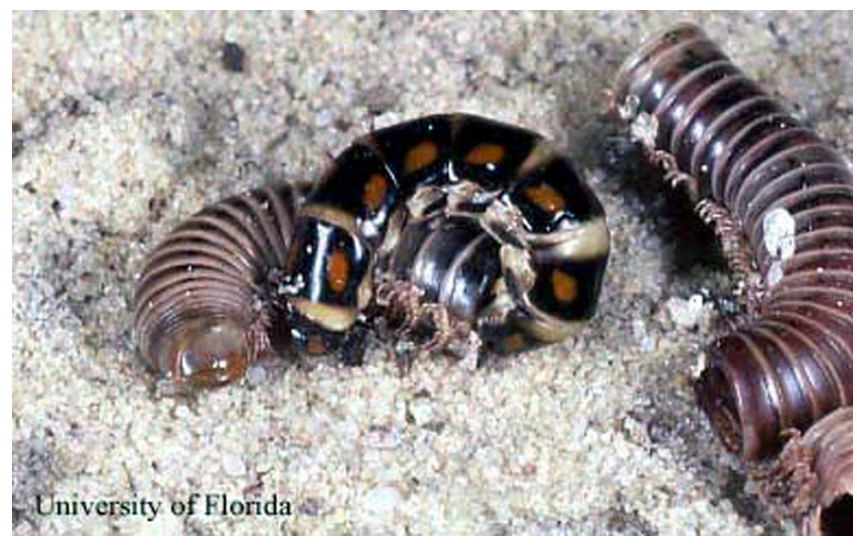

Figure 10. Phengodes sp. railroad-worm feeding on a millipede, Gainesville, FL. Credits: Photograph by: Lyle Buss, University of Florida

\section{Selected References}

Barber HS. 1906. Note on Phengodes in the vicinity of Washington, D.C. Proceedings of the Washington Entomological Society 7:196-197.

Branham MA, Wenzel JW. 2001. The evolution of bioluminescence in cantharoids (Coleoptera: Elateroidea). Florida Entomologist 4:565-586.

Costa C, Vanin SA, Casari SA, Viviani VR. 1999. Larvae of neotropical Coleoptera. XXVII Phrixothrix hirtus: immature, neotenic female, adult male and bionomic data (Phengodinae, Phengodidae, Coleoptera). Iheringia Serie Zoologia, Porto Alegre 86:9-28.

Lawrence JF, Hastings AM, Dallwitz MJ, Paine TA, Zurcher EJ. (1999). Beetles of the World: A Key and Identification System for Families and Subfamilies. (CD-ROM Version 1.0 for Windows).
CSIRO Publishing, Melbourne.

LeSage L. 1991. Phengodidae (Cantharidea) (including Rhagophthalmidae). p. 424-426 In Stehr F. (ed.) Immature Insects. Kendall/Hunt Publishing Company, Dubuque, Iowa. 975pp.

Miller R. 1997. Female Phengodes feeding and an associated risk (Coleoptera: Phengodidae). Entomological News 108:213-214.

O'Keefe S. 2002. Phengodidae LeConte 1861, p. 181-186 In Arnett Jr. R, Thomas MC, Skelly PE, Frank JH. (eds.) American Beetles. Vol. 2. CRC Press, New York, NY. 861pp.

Tiemann D. 1967. Observation on the natural history of the western banded glow-worm Zarhipis integripennis. Proceedings of the California Academy of Sciences 35:235-264.

Tiemann D. 1970. Nature's toy train, the railroad worm. National Geographic 138:58-67.

Viviani VR, Bechara JH. 1997. Bioluminescence and biological aspects of Brazilian railroad- worms (Coleoptera: Phengodidae). Annals of the Entomological Society of America 90:389-398.

Wing S. 1984. A spate of glow-worms (Coleoptera: Phengodidae). Entomological News 95:55- 57.

Wittmer W. 1975. The genus Phengodes in the United States (Coleoptera: Phengodidae). Coleopterists Bulletin 29:231-250.

Wittmer W. 1981. Zur kenntnis der Familie Phengodidae (Coleoptera). Mitteilungen der Entomologischen Gesellschaft Basel Neve Folge 31:105-107.

Zaragoza CS. 1984. Catalogo de la familia Phengodidae. Anales del Instituto de Biologia Universidad Nacional Autonoma de Mexico 55:307-324. 